\title{
IN VITRO ORGANOGENESIS IN SOME CITRUS SPECIES ${ }^{1}$
}

\author{
EVANDRO HENRIQUE SCHINOR ${ }^{2}$, FERNANDO ALVES DE AZEVEDO ${ }^{2}$, \\ FRANCISCO DE ASSIS ALVES MOURÃO FILHO², BEATRIZ MADALENA JANUZZI MENDES
}

ABSTRACT- In vitro organogenesis of citrus was studied for the genotypes Citrus sinensis cv. 'Natal', C. limonia, C. volkameriana, and C. aurantium, with the use of epicotyl segments-derived explants, cultured in MT salts and vitamins medium supplemented with different concentrations of 6-benzylaminopurine (BAP $-0.0 ; 0.5 ; 1.0 ; 1.5$, or $\left.2.0 \mathrm{mg} \mathrm{L}^{-1}\right)$. For the recalcitrant genotypes $C$. limonia and $C$. aurantium the in vitro organogenesis was also studied with internodal segments-derived explants, cultured in MT salts and vitamins medium supplemented with $0 ; 0.5 ; 1.0 ; 2.0$, or $4.0 \mathrm{mg} \mathrm{L}^{-1}$ of BAP. The efficiency of culture medium supplementation with the combination of BAP $\left(0.0 ; 1.0\right.$, or $\left.2.0 \mathrm{mg} \mathrm{L}^{-1}\right)$ and NAA (1-naphthaleneacetic acid - 0.0; 0.3 , or $\left.0.5 \mathrm{mg} \mathrm{L}^{-1}\right)$ in the development of adventitious shoots was evaluated for C. aurantium. Culture medium supplementation with BAP is not essential for the adventitious shoots development in the four genotypes studied when epicotyl segments-derived explants are used. In general, culture media supplementation with BAP decreased the percentage of responsive explants excepted for $C$. sinensis cv. 'Natal' and C. limonia when the concentrations of 1.5 and $2.0 \mathrm{mg} / \mathrm{L}^{-1}$ were used. The presence of cytokinin, in concentrations up to $2 \mathrm{mg} / \mathrm{L}^{-1}$, stimulated the in vitro organogenesis when internodal segments-derived explants were used for C. limonia and C. aurantium. For C. aurantium no adventitious shoots developed in explants (internodal segments) cultured in basal culture medium, without BAP supplementation. Although no statistic differences could be detected, culture media supplementation with the combination of BAP and NAA favored the development of adventitious shoots in C. aurantium. The best concentration of NAA varied according to BAP concentration. The results presented herein show that citrus in vitro organogenesis depends on the interaction of culture medium composition, explant differentiation level, and genotype.

Index terms: epicotyl segment, internodal segment, $C$. sinensis, $C$. limonia, $C$. volkameriana, $C$. aurantium.

\section{ORGANOGÊNESE IN VITRO EM ALGUMAS ESPÉCIES DE CITRUS}

RESUMO- A organogênese in vitro de citrus foi estudada para os genótipos Citrus sinensis cv. 'Natal', $C$. limonia, C. volkameriana e C. aurantium, utilizando-se de segmentos de epicótilo como explante, cultivados em meio de cultura MT suplementado com diferentes concentrações de 6-benzilaminopurina (BAP- 0,0; 0,5; 1,$0 ; 1,5$ ou 2,0 $\left.\mathrm{mg} \mathrm{L}^{-1}\right)$. Para os genótipos recalcitrantes $C$. limonia e $C$. aurantium, a organogênese in vitro também foi estudada, utilizando-se de segmento internodal como explante, cultivado em meio de cultura MT suplementado com $0 ; 0,5 ; 1,0 ; 2,0$ ou $4,0 \mathrm{mg} \mathrm{L}^{-1}$ de BAP. A eficiência da suplementação do meio de cultura com a combinação de $\operatorname{BAP}\left(0,0 ; 1,0\right.$ ou $\left.2,0 \mathrm{mg} \mathrm{L}^{-1}\right)$ e NAA $\left(0,0 ; 0,3\right.$ ou $\left.0,5 \mathrm{mg} \mathrm{L}^{-1}\right)$ no desenvolvimento de gemas adventícias foi avaliada para $C$. aurantium. Pode-se verificar que, nos quatro genótipos estudados, a suplementação do meio de cultura com BAP não é essencial para o desenvolvimento de gemas adventícias, quando segmentos de epicótilo são utilizados como explantes. De maneira geral, a suplementação do meio de cultura com BAP diminuiu a porcentagem de explantes responsivos, exceto para C. sinensis cv. 'Natal' e C. limonia, quando as concentrações de 1,5 e $2,0 \mathrm{mg} \mathrm{L}^{-1}$ foram utilizadas. Para C. limonia e C. aurantium, quando segmento internodal foi utilizado como explante, a presença de citocinina em concentrações até $2,0 \mathrm{mg} \mathrm{L}^{-1}$ estimulou a organogênese in vitro. No caso específico de $C$. aurantium, não ocorreu o desenvolvimento de gemas adventícias em explantes (segmento internodal) cultivados em meio de cultura basal, sem a presença de BAP. Embora não tenham sido detectadas diferenças estatísticas significativas, a suplementação do meio de cultura com a combinação BAP e NAA favoreceu o desenvolvimento de gemas adventícias em $C$. aurantium. A melhor concentração de NAA variou conforme a concentração de BAP utilizada. Pela análise dos resultados obtidos, pode-se verificar que a eficiência da organogênese in vitro de citrus depende da interação da composição do meio de cultura, do nível de diferenciação do explante e do genótipo utilizado. Termos de indexação: segmento de epicótilo, segmento internodal, C. sinensis, C. limonia, C. volkameriana, C. aurantium.

\footnotetext{
1(Trabalho 084-10). Recebido em: 26-03-2010. Aceito para publicação em: 02-12-2010.

${ }^{2}$ Escola Superior de Agricultura Luiz de Queiroz (ESALQ/USP), Departamento de Produção Vegetal, CP 9, CEP 13418-900, Piracicaba-SP. E-mails: evandro@centrodecitricultura.br; fernando@centrodecitricultura.br; famourao@esalq.usp.br

${ }^{3}$ Centro de Energia Nuclear na Agricultura (CENA/USP), Laboratório de Biotecnologia Vegetal, CP 96, CEP 13400-970 PiracicabaSP. E-mail: bmendes@cena.usp.br ( autor correspondente)
} 


\section{INTRODUCTION}

Citrus in vitro organogenesis has been studied since 1982 with the report of adventitious shoot development in 5 different Citrus species (BARLASS; SKENE, 1982). The main interest of the primary studies was the micropropagation of the progeny obtained from breeding programs, or the micropropagation of both monoembryonic cultivars, and cultivars that produce few seeds (BORDÓN et al., 2000; GARCÍA-LUIS et al., 2006). Recently, with the development of genetic transformation techniques the interest in in vitro organogenesis protocol has increased. It is well know that the success of a genetic transformation program depends on the availability of an in vitro protocol that permits the regeneration of a high number of plants (GARCÍALUIS et al., 2006).

Although in vitro organogenesis has been described for many citrus genotypes, some species and cultivars have shown to be recalcitrant to the process. A high regenerative capacity has been observed for Poncirus trifoliata hybrids, such as 'Carrizo' and 'Troyer' citranges (BORDÓN et al., 2000; MOREIRA-DIAS et al., 2001). However some important rootstock genotypes such as $C$. limonia, $C$. volkameriana, and C. aurantium have shown some recalcitrance to the process (BARLASS; SKENE, 1982; BORDÓN et al., 2000; COSTA et al, 2004). In some cases, even cultivars of the same species show different requirements for in vitro culture (SCHINOR et al., 2006). Difficulties in regenerating in vitro plants reflect in genetic transformation efficiency making more difficult to obtain transgenic plants.

The results obtained so far show that the success of citrus in vitro organogenesis is dependent of culture media composition (KHAN et al., 2009), incubation conditions (BORDÓN et al., 2000; MOREIRA-DIAS et al., 2001; GARCÍA-LUIS et al., 2006; MOLINA et al., 2007), and explants type (MOREIRA-DIAS et al., 2001; KHAN et al., 2009). The best results have been obtained with the use of epicotyl or internodal segments-derived explants collected from young plants (PÉREZ-MOLPHEBALCH; OCHOA-ALEJO, 1997), cultivated in culture media supplemented with cytokinin (BORDÓN et al., 2000; MOREIRA-DIAS et al., 2000).

In the present study it was evaluated in vitro organogenesis of four citrus genotypes Citrus sinensis cv. 'Natal', C. limonia, C. volkameriana, and $C$. aurantium, considering culture media and explant type. The protocol developed might be used for genetic transformation experiments of these species.

\section{MATERIAL AND METHODS}

Plant material. Seeds were extracted from mature fruits of $C$. sinensis cv. 'Natal', C. limonia, $C$. volkameriana, and $C$. aurantium, and dried at room temperature $(24 \mathrm{~h})$. The seed coat was removed and the seeds were treated with sodium hypochlorite solution ( $0.5 \%$ active chloride, $20 \mathrm{~min})$, followed by three rinses with sterile distilled water. The seeds were cultured in test tubes $(25 \times 150 \mathrm{~mm})$ containing $15 \mathrm{~mL}$ of MT solid medium (MURASHIGE; TUCKER, 1969) and incubated in the dark at 27 ${ }^{\circ} \mathrm{C}$, for 2 - 3 weeks. Seedlings of $12-15 \mathrm{~cm}$ height were transferred to 16 -h photoperiod for 10 days. After this period the seedlings were used as source of explants, consisted of epicotyl segments $(0.8-1$ $\mathrm{cm})$. C. limonia and C. aurantium plants derived from seeds were also cultivated in plastic bags ( 35 x $20 \mathrm{~cm}$ ) containing commercial pot mix Rendmax citrus (Eucatex, SP, Brazil) in greenhouse conditions. The plants were pruned keeping the main stem. Developed lateral shoots ( $2-3$ weeks) were collected and disinfested in sodium hypochlorite solution (1\% active chloride, $30 \mathrm{~min}$ ), followed by three rinses with sterile distilled water.

In vitro organogenesis. Epicotyl segments of C. sinensis cv. 'Natal', C. limonia, C. volkameriana, and $C$. aurantium derived from in vitro germinated seeds were horizontally incubated in Petri dish (100 x $15 \mathrm{~mm}$ ) containing MT salts and vitamins medium (MURASHIGE; TUCKER, 1969) supplemented with $0,0.5,1.0,1.5$, or $2.0 \mathrm{mg} \mathrm{L}^{-1}$ 6-benzylaminopurine (BAP). The experimental design was completely randomized with five replications. Each replication consisted of a Petri dish with 12 explants.

In vitro organogenesis of $C$. limonia and C. aurantium were also evaluated with the use of internodal segments as explants derived from plants cultivated in greenhouse. The internodal segments were horizontally incubated in Petri dish containing MT salts and vitamins medium supplemented with the $0,0.5,1.0,2.0$, or $4.0 \mathrm{mg} \mathrm{L}^{-1}$ of BAP. The experimental design was completely randomized with five replications. Each replication consisted of a Petri dish with 10 explants.

Sour orange in vitro organogenesis was also evaluated culturing internodal segments, derived from plants cultivated in greenhouse, in Petri dish containing MT salts and vitamins medium supplemented with the combination of $0,1.0$, or $2.0 \mathrm{mg} \mathrm{L}^{-1}$ of BAP in combination with $0,0.3$, or $0.5 \mathrm{mg} \mathrm{L}^{-1}$ of NAA. The experimental design was completely randomized with five replications. Each replication 
consisted of a Petri dish with 14 explants.

All culture medium were solidified with agar (8.0 $\mathrm{g} \mathrm{L}^{-1}$, Sigma), $\mathrm{pH} 5.8$, and sterilized by autoclaving $\left(120^{\circ} \mathrm{C}, 20 \mathrm{~min}\right)$. The incubation was at $27{ }^{\circ} \mathrm{C}$, in the dark, for 20 days, followed by 25 days incubation under $16 \mathrm{~h}$ photoperiod. The evaluation was performed on a stereomicroscope (Zeiss, Oberkochen, Germany) determining the number of responsive explants, with the development of adventitious shoots, and the number of shoots per explant.

\section{RESULTS AND DISCUSSION}

The most frequently evaluated variables for the development of citrus tissue culture protocols have been culture media composition and explants type (BARLASS; SKENE, 1982; MOREIRA-DIAS et al., 2000; COSTA et al., 2004). Table 1 shows the results of in vitro organogenesis using epicotyl segments-derived explants with the four genotypes studied. The culture medium supplementation with BAP was not essential for adventitious shoot development. A high percentage of responsive explants were obtained using basal medium, without cytokinin supplementation. Considering $C$. sinensis cv. 'Natal' and C. limonia culture media supplementation with 0.5 and $1.0 \mathrm{mg} \mathrm{L}^{-1}$ decreased the percentage of responsive explants. However, increasing BAP concentrations to $1.5-2.0 \mathrm{mg} \mathrm{L}^{-1}$ in vitro organogenesis was stimulated resulting in explants responsiveness values similar to control treatment. Regarding to C. volkameriana and $C$. aurantium the culture media supplementation with BAP resulted in a drastic decrease in the percentage of responsive explants. Apparently BAP is more related with the number of shoots developed per explant as the culture media supplementation with the cytokinin increased the number of adventitious shoots developed in C. sinensis cv. 'Natal' and C. limonia. For C. volkameriana the number of shoots developed per explant increased with BAP concentrations up to 1.5 $\mathrm{mg} \mathrm{L}^{-1}$. BAP did not favor in vitro organogenesis in $C$. aurantium using epicotyl segments-derived explants considering the two evaluated variables.

Although it is well reported that citrus in vitro organogenesis is favored by culture media supplementation with cytokinin (MOREIRA-DIAS et al., 2000) the development of adventitious shoots may occur in basal medium, especially when very young explants are used (ALMEIDA et al., 2002; COSTA et al., 2004). This phenomenon was also detected in our work with the four genotypes studied considering the use of epicotyl segments-derived explants. In fact, for C. limonia, C. volkameriana, and $C$. aurantium the culture media supplementation with
BAP reduced the percentage of responsive explants. For the genotypes studied herein, BAP culture media supplementation seemed to be more related with the number of shoots developed per explants than with organogenesis induction.

The in vitro organogenesis process was also studied for $C$. limonia and $C$. aurantium using internodal segments collected from ex vitro-grown plants (Table 2). For C. limonia no significant difference was detected between the cytokinin media supplementation treatments and the control treatment. The explant responsiveness ranged from 52\% in the control treatment (without BAP) to $82 \%$ with $2.0 \mathrm{mg} \mathrm{L}^{-1}$ of BAP. The number of shoots per explant ranged from 1.3 to 2.1 among the treatments. The results obtained for internodal segments followed the same trend observed with the use of epicotyl segments (Table 1). In contrast, for $C$. aurantium when using internodal segments as explants the culture media supplementation with BAP showed to be essential for in vitro organogenesis. The percentage of responsive explants increased up to 2.0 $\mathrm{mg} \mathrm{L}^{-1}$ of BAP with values ranging from $0.0-48 \%$. The highest concentration of BAP $\left(4.0 \mathrm{mg} \mathrm{L}^{-1}\right) \mathrm{did}$ not favor the in vitro organogenesis resulting in $10 \%$ of responsive explants. Although the presence of cytokinin was essential for organogenesis, no significant difference was detected among the treatments for the number of shoots per explant. For this genotype the explants epicotyl and internodal segments showed different behavior regarding to cytokinin culture media supplementation requirement. Contrasting with the results obtained for epicotyl segments-derived explants, no adventitious shoots developed in internodal segments-derived explants cultured in basal media. Tavano et al. (2009) also detected that BAP culture media supplementation is an essential requisite for adventitious shoots development when internodal segments-derived explants of $C$. volkameriana and C. aurantium were in vitro cultured. For both cultivars studied here, the highest BAP concentration (4.0 $\left.\mathrm{mg} \mathrm{L}^{-1}\right)$ inhibited adventitious shoots development. The inhibitory effect of high concentrations of BAP has also been reported for other citrus genotypes such as 'Troyer' citrange, 'Cleopatra', and 'Clementine' mandarins (MOREIRA-DIAS et al., 2000; MOLINA et al., 2007; CERVERA et al., 2008).

The in vitro organogenesis of the most recalcitrant genotype $C$. aurantium, was also studied with the supplementation of the culture media with the combination of BAP and NAA. The results presented in this study, confirmed the influence of cytokinin in organogenesis of $C$. aurantium from internodal 
segments-derived explants as no adventitious shoots were obtained without the use of BAP (Table 3 ). The explant responsiveness increased with the use of NAA in combination with BAP. The best concentration of NAA varied according to BAP concentration. The number of shoots per explant was not influenced by the treatments evaluated.

The results reported herein indicate that besides culture media composition and explant type, there is a marked influence of genotype in the success of in vitro culture (BORDÓN et al., 2000). Among Citrus and other related genera, Poncirus trifoliata related hybrids show the best efficiency for in vitro organogenesis with the highest regeneration capacity (BARLASS; SKENE, 1982). Most frequently, these genotypes show $100 \%$ of explants with adventitious shoots development (BORDÓN et al., 2000; MOREIRA-DIAS et al., 2001; SCHINOR et al., 2006). Regarding to explants responsiveness, C. sinensis may be considered an intermediate spe- cies with values of responsive explants, when young explants such as epicotyl segments are used, ranging from 60 - 90\% (BORDÓN et al., 2000; ALMEIDA et al., 2002). The rootstock genotypes $C$. limonia, $C$. volkameriana, and $C$. aurantium may be considered recalcitrant to the in vitro culture and plant regeneration through organogenesis. The results reported herein confirmed this information and the difficulties in obtaining adventitious shoots development increase with the use of more differentiated explants.

However, some species are recalcitrant to in vitro culture even using young explants and different culture media. This is the case of C. aurantium which the best percentage of responsive explants obtained in this study was $60 \%$ using the less differentiated explant, i.e. epicotyl segments. The supplementation of culture media with the combination of BAP and NAA did not result in an increase of the percentage of responsive explants. The results obtained here for $C$. aurantium indicate that some internal characteristic of the species may be impairing the in vitro culture.

TABLE 1 - In vitro organogenesis from epicotyl segments-derived explants from Citrus sinensis cv. Natal, C. limonia, C. volkameriana, and C. aurantium.

\begin{tabular}{lccc}
\hline \multicolumn{1}{c}{ Genotypes } & $\begin{array}{c}\text { BAP } \\
\left(\mathrm{mg} \mathrm{L}^{-1}\right)\end{array}$ & $\begin{array}{c}\text { Responsive explants } \\
(\%)\end{array}$ & Number of shoots/explant \\
\hline C. sinensis cv. Natal & 0.0 & $56.7 \mathrm{ab}$ & $1.2 \mathrm{c}$ \\
& 0.5 & $43.4 \mathrm{ab}$ & $1.8 \mathrm{bc}$ \\
& 1.0 & $33.3 \mathrm{~b}$ & $2.0 \mathrm{bc}$ \\
& 1.5 & $64.6 \mathrm{a}$ & $2.8 \mathrm{ab}$ \\
& 2.0 & $60.0 \mathrm{ab}$ & $3.2 \mathrm{a}$ \\
C. limonia & & & \\
& 0.0 & $66.7 \mathrm{a}$ & $1.3 \mathrm{a}$ \\
& 0.5 & $33.9 \mathrm{~b}$ & $1.7 \mathrm{a}$ \\
& 1.0 & $35.6 \mathrm{~b}$ & $1.9 \mathrm{a}$ \\
& 1.5 & $55.4 \mathrm{ab}$ & $2.4 \mathrm{a}$ \\
& 2.0 & $61.7 \mathrm{ab}$ & $2.3 \mathrm{a}$ \\
& & & \\
& 0.0 & $66.7 \mathrm{a}$ & $1.1 \mathrm{~b}$ \\
& 0.5 & $66.7 \mathrm{a}$ & $2.9 \mathrm{a}$ \\
& 1.0 & $38.3 \mathrm{~b}$ & $2.9 \mathrm{a}$ \\
& 1.5 & $27.1 \mathrm{~b}$ & $2.0 \mathrm{ab}$ \\
& 2.0 & $18.0 \mathrm{~b}$ & $0.8 \mathrm{~b}$ \\
& & & \\
& 0.0 & $60.0 \mathrm{a}$ & $1.4 \mathrm{a}$ \\
& 0.5 & $8.3 \mathrm{~b}$ & $0.0 \mathrm{~b}$ \\
& 1.0 & $0.0 \mathrm{~b}$ & $0.2 \mathrm{~b}$ \\
& 1.5 & $1.7 \mathrm{~b}$ & $0.6 \mathrm{ab}$ \\
\hline
\end{tabular}

Mean of five replications with 12 explants each, totaling 60 explants per treatment. Means followed by different letters in the column are significantly different by Tukey's test $(\mathrm{p}=0.05)$. 
TABLE 2 - In vitro organogenesis from internodal segments-derived explants from Citrus limonia and C. aurantium.

\begin{tabular}{lccc}
\hline \multicolumn{1}{c}{ Genotypes } & BAP $\left(\mathrm{mg} \mathrm{L}^{-1}\right)$ & Responsive explants $(\%)$ & Number of shoots/explant \\
\hline C. limonia & 0.0 & $52.0 \mathrm{ab}$ & $1.3 \mathrm{ab}$ \\
& 0.5 & $36.6 \mathrm{~b}$ & $1.2 \mathrm{~b}$ \\
& 1.0 & $62.0 \mathrm{ab}$ & $1.4 \mathrm{ab}$ \\
& 2.0 & $82.0 \mathrm{a}$ & $1.9 \mathrm{ab}$ \\
C. aurantium & $54.0 \mathrm{ab}$ & $2.1 \mathrm{a}$ \\
& 0.0 & $0.0 \mathrm{c}$ & $0.0 \mathrm{~b}$ \\
& 0.5 & $40.0 \mathrm{ab}$ & $1.4 \mathrm{a}$ \\
& 1.0 & $38.0 \mathrm{ab}$ & $1.2 \mathrm{a}$ \\
& 2.0 & $48.8 \mathrm{a}$ & $1.6 \mathrm{a}$ \\
& 4.0 & $10.0 \mathrm{bc}$ & $1.2 \mathrm{a}$ \\
\hline
\end{tabular}

Mean of five replications with 10 explants each, totaling 50 explants per treatment. Means followed by different letters in the column are significantly different by Tukey's test $(\mathrm{p}=0.05)$.

TABLE 3 - In vitro organogenesis from internodal segments-derived explants from Citrus aurantium, cultured in culture media supplemented with the combination of BAP + NAA.

\begin{tabular}{ccc}
\hline BAP + NAA $\left(\mathrm{mg} \mathrm{L}^{-1}\right)$ & Responsive explants $(\%)$ & Number of shoots/explant \\
\hline $0.0+0.0$ & $0.0 \mathrm{c}$ & $0.0 \mathrm{~b}$ \\
$0.0+0.3$ & $0.0 \mathrm{c}$ & $0.0 \mathrm{~b}$ \\
$0.0+0.5$ & $0.0 \mathrm{c}$ & $0.0 \mathrm{~b}$ \\
$1.0+0.0$ & $17.6 \mathrm{bc}$ & $1.0 \mathrm{a}$ \\
$1.0+0.3$ & $14.9 \mathrm{bc}$ & $1.1 \mathrm{a}$ \\
$1.0+0.5$ & $36.4 \mathrm{ab}$ & $1.5 \mathrm{a}$ \\
$2.0+0.0$ & $21.0 \mathrm{abc}$ & $1.3 \mathrm{a}$ \\
$2.0+0.3$ & $51.9 \mathrm{a}$ & $1.6 \mathrm{a}$ \\
$2.0+0.5$ & $37.1 \mathrm{ab}$ & $1.6 \mathrm{a}$ \\
\hline
\end{tabular}

Mean of five replications with 14 explants each, totaling 70 explants per treatment. Means followed by different letters in the column are significantly different by Tukey's test $(p=0.05)$.

\section{CONCLUSIONS}

There is an interaction among culture media composition, explant level of differentiation, and genotype, for the development of citrus in vitro adventitious shoots. For the more recalcitrant genotypes, the best results are obtained with the use of less differentiated explants.

\section{ACKNOWLEDGMENTS}

The authors acknowledge Fundação de Amparo a Pesquisa do Estado de São Paulo (FAPESP), Conselho Nacional de Desenvolvimento Científico e Tecnológico (CNPq), Coordenação de Aperfeiçoamento de Pessoal de Nível Superior (CAPES), and Fundo de Defesa da Citricultura (Fundecitrus) for research financial support and research fellowships.

\section{REFERENCES}

ALMEIDA, W.A.B.; MOURÃO FILHO, F.A.A.; MENDES, B.M.J.; RODRIGUEZ, A.P.M. In vitro organogenesis optimization and plantlet regeneration in Citrus sinensis and C. limonia. Scientia Agricola, Piracicaba, v.59, n.1, p.35-40, 2002.

BARLASS, M.; SKENE, K.G.M. In vitro plantlet formation from Citrus species and hybrids. Scientia Horticulturae, Amsterdam, v.17, n.4, p.333-341, 1982.

BORDÓN, Y.; GUARDIOLA, J.L.; GARCÍA-LUIS, A. Genotype affects the morphogenic response in vitro of epicotyl segments of Citrus rootstocks. Annals of Botany, London, v.86, p.159-166, 2000. 
CERVERA, M.; NAVARRO, A.; NAVARRO, L.; PEÑA, L. Production of transgenic adult plants from Clementine mandarin by enhancing cell competence for transformation and regeneration. Tree Physiology, Victoria, v.28, p.55-66, 2008.

COSTA, M.G.C.; ALVES, V.S.; LANI, E.R.G.; MOSQUIMA, P.R.; CARVALHO, C.R.; OTONI, W.C. Morphogenic gradients of adventitious bud and shoot regeneration in epicotyl explants of Citrus. Scientia Horticulturae, Amsterdam, v.100, p.63-74, 2004.

GARCÍA-LUIS, A.; MOLINA, R.V.; VARONA, V.; CASTELLÓ, S.; GUARDIOLA, J.L. The influence of explant orientation and contact with the medium on the pathway of shoot regeneration in vitro in epicotyl cuttings of Troyer citrange. Plant Cell, Tissue and Organ Culture, Dordrecht, v.85, n.2, p.137-144, 2006.

KHAN, E.U.; FU, X.Z.; WANG, J.; FAN, Q.J.; HUANG, X.S.; ZHANG, G.N.; SHI, J.; LIU, J.H. Regeneration and characterization of plants derived from leaf in vitro culture of two sweet orange (Citrus sinensis (L.) Osbeck) cultivars. Scientia Horticulturae, Amsterdam, v.120, p.70-76, 2009.

MOLINA, R.V.; CASTELLO, S.; GARCÍA-LUIS, A.; GUARDIOLA, J.L. Light cytokinin interactions in shoot formation in epicotyl cuttings of Troyer citrange cultured in vitro. Plant Cell, Tissue and Organ Culture, Dordrecht, v.89, n.2-3, p.131-140, 2007.
MOREIRA-DIAS, J.M.; MOLINA, R.V.; BORDÓN, Y.; GUARDIOLA, J.L.; GARCÍA-LUIS, A. Direct and indirect shoot organogenic pathways in epicotyl cuttings of Troyer citrange differ in hormone requirements and in their response to light. Annals of Botany, London, v.85, p.103-110, 2000.

MOREIRA-DIAS, J.M.; MOLINA, R.V.; GUARDIOLA, J.L.; GARCÍA-LUIS, A. Daylength and photon flux density influence the growth regulator effects on morphogenesis in epicotyl segments of Troyer citrange. Scientia Horticulturae, Amsterdam, v.87, p.275-290, 2001.

MURASHIGE, T.; TUCKER, D.P.H. Growth factor requirement of citrus tissue culture. In: INTERNATIONAL CITRUS SYMPOSIUM, 1., 1969, Riverside. Proceeding... Riverside: University of California. 1969. p.1155-1169.

PÉREZ-MOLPHE-BALCH, E; OCHOA-ALEJO, $\mathrm{N}$. In vitro plant regeneration of Mexican lime and mandarin by direct organogenesis. HortScience, Alexandria, v.32, p.931-934, 1997.

SCHINOR, E.H.; PAOLI, L.G.; AZEVEDO, F.A.; MOURÃO FILHO, F.A.A.; MENDES, B.M.J. Organogênese in vitro a partir de diferentes regiões do epicótilo de Citrus sp. Revista Brasileira de Fruticultura, Jaboticabal, v.28, p.463-466, 2006.

TAVANO, E.C.R.; STIPP, L.C.L.; MUNIZ, F.R.; MOURÃO FILHO, F.A.A.; MENDES, B.M.J. In vitro organogenesis of Citrus volkameriana and Citrus aurantium. Biologia Plantarum, Praha, v.53, n.2, 2009. 